\title{
A double blind clinical trial evaluating the relative pharmacokinetics and bioavailability of oral creatine monohydrate when combined with either isomaltulose or dextrose in healthy adult males
}

\author{
Douglas S Kalman*, Samantha Feldman, Howard I Schwartz, Diane R Krieger \\ From International Society of Sports Nutrition: 9th Annual ISSN Conference and Expo \\ Clearwater, FL, USA. 22-23 June 2012
}

\section{Background}

Isomaltulose (6-0- $\alpha$-D-glucopyranosyl-D-fructose) is a low-glycemic, low-insulinemic disaccharide that is absorbed more slowly than conventional sugars (monosaccharides). In sports nutrition, creatine monohydrate is often combined with dextrose (a monosaccharide) for the purpose of enhanced absorption and cellular uptake.

\begin{abstract}
Methods
In a prospective, randomized, double blind, active-comparator-controlled, parallel group pilot study, 30 male subjects, age $27.0 \pm 4.6$ years, with BMI of $24.75 \pm 1.99$ $\mathrm{kg} / \mathrm{m}^{2}$ and a body surface area (BSA) of $1.953 \pm 00.75$ $\mathrm{m}^{2}$, were randomly assigned to ingest 3 grams of creatine monohydrate $(\mathrm{CM})$ in combination with isomaltulose (ISO) or dextrose (DEX) in 1 of 3 concentrations (5 gm liquid, $17 \mathrm{gm}$ capsules or $50 \mathrm{gm}$ liquid). Rate of absorption $\left(\mathrm{t}_{\mathrm{Max}}\right)$ and overall absorption (from BSA adjusted $\mathrm{AUC}_{0-8 \mathrm{~h}}$ and $\mathrm{C}_{\mathrm{Max}}$ ) of $\mathrm{CM}$ was determined via changes in serum creatine over an 8-hour test period. Blood was collected at baseline and 0.5, 1, 2.5, 4 and 8 hours post ingestion with efficacy endpoints including $\mathrm{C}_{\text {Max }}, \mathrm{t}_{\mathrm{Max}}, \mathrm{AUC}_{0-8 \mathrm{~h}}$ and $\lambda_{\text {Elim }}$ derived from normalized concentration vs. time curves for serum creatine (AUC by trapezoidal integration). Serum creatine levels were normalized by BSA using the Mosteller formula. For PK parameters, paired Student $t$ test (or Wilcoxon if non-
\end{abstract}

\footnotetext{
* Correspondence: dkalman@miamiresearch.com

Miami Research Associates. 6141 Sunset Drive Suite 301, Miami, FL. 33143,
} USA

() 2012 Kalman et al; licensee BioMed Central Ltd. This is an Open Access article distributed under the terms of the Creative Commons Attribution License (http://creativecommons.org/licenses/by/2.0), which permits unrestricted use, distribution, and reproduction in any medium, provided the original work is properly cited. normally distributed) was used and for categorical variables, Fisher Exact test (or Chi-Square if necessary) was used. Statistics were calculated by $R$ v2.14.0 (www.r-project.org).

\section{Results}

For the 17 gm concentrations, ISO had a significantly higher $\mathrm{C}_{\mathrm{Max}}$ than DEX $(18.1 \pm 1.5$ vs $12 \pm 1.6 \mathrm{mg} /$ $\left.\mathrm{dl}^{*} \mathrm{~m}^{2} ; \mathrm{p}<0.001\right)$ and for the $50 \mathrm{gm}$ concentrations, the $\mathrm{C}_{\text {Max }}$ trended higher for ISO than DEX $(19.1 \pm 6.4$ vs $\left.13.1 \pm 3.3 \mathrm{mg} / \mathrm{dl}^{*} \mathrm{~m}^{2} ; \mathrm{p}=0.099\right)$. The AUC for the $50 \mathrm{gm}$ concentration was significantly higher for ISO than DEX $(54.6 \pm 9.2$ vs $40.3 \pm 10 ; \mathrm{p}=0.046)$. The 17 gm $(1.9 \pm 0.8$ hrs) and $50 \mathrm{gm}(1.3 \pm 0.7 \mathrm{hrs})$ concentrations were associated with larger $t_{M a x}$, which trended toward significance over the $5 \mathrm{gm}$ concentration $(1 \pm 0 \mathrm{hrs})$ for ISO $(\mathrm{p}=0.078)$ and was not significant for DEX. For all 3 concentrations, the $\mathrm{C}_{\mathrm{Max}}$ and $\mathrm{AUC}$ were significantly higher for ISO than DEX $(17.8 \pm 4.7$ vs $13.5 \pm 2.8 \mathrm{mg} /$ $\mathrm{dl}^{*} \mathrm{~m}^{2}$ and $50.8 \pm 17.1$ vs $38.8 \pm 10.3 ; \mathrm{p}=0.005$ and $\mathrm{p}=0.027$ respectively).

\section{Conclusions}

$\mathrm{CM}$ appears to be absorbed more efficiently when combined with ISO over DEX supported by a significantly higher $\mathrm{C}_{\max }$ for the $17 \mathrm{~g}$ concentration and a significantly higher AUC for the $50 \mathrm{~g}$ concentration. The 17 and $50 \mathrm{gm}$ formulations appear to be superior to the 5 gm concentration. ISO appears to be a beneficial carbohydrate for facilitating the delivery of creatine to the body. 


\section{Acknowledgements}

Hong Kong Life Sciences Company Limited. Wanchai, Hong Kong.

Published: 19 November 2012

doi:10.1186/1550-2783-9-S1-P14

Cite this article as: Kalman et al:: A double blind clinical trial evaluating the relative pharmacokinetics and bioavailability of oral creatine monohydrate when combined with either isomaltulose or dextrose in healthy adult males. Journal of the International Society of Sports Nutrition 2012 9(Suppl 1):P14.

Submit your next manuscript to BioMed Central and take full advantage of:

- Convenient online submission

- Thorough peer review

- No space constraints or color figure charges

- Immediate publication on acceptance

- Inclusion in PubMed, CAS, Scopus and Google Scholar

- Research which is freely available for redistribution

Submit your manuscript at www.biomedcentral.com/submit
C Biomed Central 